\title{
Finding home: Black queer historical scholarship in the United States Part I
}

\section{Jennifer Dominique Jones (i)}

University of Michigan

Correspondence

Jennifer Dominique Jones, LSA Collegiate Fellow, Department of History, University of Michigan, 435 South State Street, 1029 Tisch Hall, Ann Arbor, MI 48109.

Email: jonejenn@umich.edu

\section{1 | INTRODUCTION}

On April 17, 2017, the New Yorker published a review of Rosalind Rosenberg's (2017) book Jane Crow: The Life of Pauli Murray (2017). Written by Pulitzer Prize winning journalist Kathryn Shultz, the review enthusiastically surveys the exhaustive biography of a Baltimore, Maryland-born Durham, North Carolina-raised woman of African descent's multifaceted life: her career as a lawyer, activist, and Episcopal Priest; her organizational work including as a founding member of the National Organization for Women and the Congress of Racial Equality; and her intellectual contributions which include critical theorizations of gender and racial discrimination. For Schultz, however, it is Murray's "private struggles" with gender identity as well as "her public struggles on behalf of women, minorities, and the working class" that spurs recent interest her life. "Historical figures," she argues "aren't human flotsam, swirling into public awareness at random intervals. Instead they are almost always born back to us on the current of our own times." Schutlz's formulation of history (and historical memory) as linear and progressive undergird the assertion that Murray's "struggles" are an important historical touchstone for transgender and non-binary communal visibility and continuing struggles against sexism, racism and queer phobia. ${ }^{1}$

Such unidirectional currents are not the only oceanic formations to appear within considerations of black queer history. In her important essay "black Atlantic, Queer Atlantic: Queer Imaginings of the Middle Passage," literary scholar Omise'eke Natasha Tinsley $(2008,199)$ mobilizes "cross-currents" as a way of thinking about the historical relationship between blackness and queerness at the origin of black diasporic experience: The Middle Passage. Using an "unconventional and imaginative archive" of academic theorizing and literature, Tinsley calls for analytical frameworks that permit the possibility of same-sex intimacies in the holds of the slave ship, albeit not "to clarify, to tell a documentable story of Atlantic, Caribbean, Immigrant or 'gay' pasts." Rather, this shift in vision encourages a recognition of the concurrent historical existence of "brutality and desire, genocide and resistance," aboard the slave ship as a way "to view hybrid, resistant subjectivities- opaquely, not transparently."

I begin with these watery movements because they raise a number of questions about scholarly interrogations of blackness and queerness in United States history: What is revealed when one places histories of black racial formation alongside histories of non-normative sexualities (and same-sex sexualities in particular)? To what extent has a desire to identify queer forbears and consider their lives/labors as models for the present informed scholarly inquiries? What is the transformative potential of centering black queer lives in historical narratives about political, 
social, and cultural movements in the United States? How do scholars navigate the limits of traditional archives while continuing to consult these spaces for "knowledge"? Have scholars adopted particular analytical frameworks for writing about sexual/gender subjectivities in earlier moments that confound binaries, categorization, "evidentiary" frameworks, and even naming? ${ }^{2}$

This essay surveys black queer historical scholarship, identifying prominent themes, topics, and methods. These works share two broad concerns. First, the texts chronicle how people of African descent understood, articulated, and expressed various forms of sexual and gender difference, with a particular focus on same-sex intimacies and gender transgression. ${ }^{3}$ Second, many of these works analyze the intersections of queerness and blackness as concepts of non-normativity (in medical texts, literature/performance, popular culture, political rhetoric, etc.). In this essay, I most often use "queer" as a broad term for intimacies, subjectivities, and ways of being increasingly associated with lesbian, gay, bisexual, transgender, and queer (LGBTQ) constituencies during the second half of the twentieth century. However, the term's call to destabilize categories of identification and expose the process of normalization that marks some bodies/behaviors as "normal" and others as "deviant" animates much of the cited scholarship. These works employ a wide range of methods and move between/within various (inter)disciplinary "homes"-including history, literary studies, sociology, cultural studies, black queer studies, performance studies, critical race theory, and black feminist theory. ${ }^{4}$

Essay 1 of this survey considers various "origin points" of black queer histories. These "origins points" include intellectual and political genealogies, challenges and responses to the creation of black queer histories (including erasure, (re) constitution of evidence and methods), considerations of "visibility" as a framework for "finding" black queer subjects, and two early temporal intersections of blackness and queerness: the sexual economies of American slavery and turn of the twentieth century discourses and urban spaces. Essay II charts the (largely) scholarly landscape, identifying four topical areas: black "Lesbian" Histories, Histories of Gender Transgression, black communities, class and histories of belonging and communal/political formations. Space, time, and the increasing amount of germane scholarship do not permit me to cite or discuss every work that addresses various historical intersections of blackness and queerness. I offer this essay as one point of entry into this growing area of inquiry.

\section{2 | GENEALOGIES, METHOD, AND THE DESIRE FOR RECOVERY}

"Nature," author Jewelle Gomez (n.d., 122) notes "abhors a vacuum and there is a distinct gap in the picture where the black Lesbian should be." Although written in 1983, this characterization of black lesbian invisibility applied to a lack of scholarly, artistic, and popular representations of black LGBTQ communities. These absences prompted Gomez and other black lesbian/gay culture workers of the 1970s, 1980s, and 1990s to lovingly (re)construct histories and narratives that would "create a ... record that is placed in a historical perspective so that we, who have been lost in the shadows of the past, can be revealed and appreciated for the powerful legacy we bear." Memoirs like Audre Lorde's Zami: A New Spelling of My Name (Lorde, 1982), literary analyses by writers like Akasha (Gloria) Hull (Hull, n.d.), works of fiction like Loving Her by Ann Allen Shockley, and films like Isaac Julien's Looking for Langston (Marsh-Edwards \& Julien, 1989) and Cheryl Dunye's The Watermelon Woman (Dunye, 1996) stand as critical cultural efforts to document and imagine black queer histories. ${ }^{4}$

The gap-although diminishing-persists. There continues to be, as Robert Reid-Pharr $(2006,1)$ notes, "many places at which it is difficult if not impossible to answer basic questions about history and ideology, practice and attitude." Homophobia and racism (past and present) fuel the exclusion of black queer perspectives from archival holdings and finding aids. Too, the possibility that-to quote historian Michele Mitchell (1999, p. 434)-"certain subjects are avoided [by scholars] because they have been deemed either dangerous or damaging" by African Americanists lingers. Assumptions of black heterosexuality, the ubiquity of homophobia within black communities, and conflations of queerness with whiteness engender scholarly myopia. 
Many black queer histories act as distributaries of U.S. LGBT History and African American History fields, departing from and disrupting prominent narratives and assumptions. Challenging the presumed whiteness of LGBTQ subjectivities, communities and politics is one critical intervention. As Allan Bérubé (2001, p. 206) notes, the racial homogeneity of many gay political institutions in the post-World War II period, "created a powerful camouflage of the presence of race woven from a web of unquestioned beliefs- that gay whiteness is unmarked and unremarkable, universal and representative, powerful and protective, a cohesive bond." This "unmarked"-ness and the profound underrepresentation of people of color in LGBTQ archival collections facilitates these absences (including a sustained analysis of whiteness). This state of affairs may reflect racism within gay/lesbian institutions and other ways of black queer social organization that decenter(ed) "coming out" as a central strategy. As Marlon Ross (2005, p. 181) suggests, a "continuum of knowing" within black communities about gender and sexual transgression along with other factors may have created "culturally variant" forms of identification. This provocation will continue to inspire studies of black queer life that center both a politics of recognition and other ways of being.

Black queer histories also challenge assumptions of black heterosexuality and archival silences about black intimate life. The latter has multiple origin points, including the ubiquity of two theoretical frameworks within African American historiography. As Mitchell notes, the politics of respectability-with its emphasis on contemporary propriety as a form of resistance to white supremacist narratives of black sexual depravity (Higginbotham, 1993) and the culture of dissemblance in which black women in particular kept their intimate lives (especially experiences of sexual violence) hidden from public scrutiny (Hine, 1989)-are crucial forms of resistance to racial terrorism and discrimination. Creators of black queer histories not only challenge the assumed prevalence of these strategies but also nuance scholarly understandings about the operation and deployment of these particular strategies in the past.

Archivists, activists, and scholars adopt a ranch of approaches to address the very tangible dearth of archival evidence. Creative analytical methods are crucial and include reading primary sources for the voices/perspectives of the most marginal, incorporating literary and cultural analysis and seeking sexual/gender transgression in prominent/obscure archival collections. The creation of black LGBTQ archives is another crucial response to silence. Archival/oral history initiatives include but are not limited to the In the Life Archive (curated by Stephen G. Fullwood, Schomburg Center for Research on black Life), the black Queer Mobile Homecoming Project (collected by Alexis Pauline Gumbs and Julia Roxanne Wallace), the community-directed Queer History Newark project, and the African American AIDS Activism Oral History Project (collected by historian Dan Royles). These (and forthcoming) collections are rich foam from which various historically minded projects about black queer subjectivities will surely emerge.

In addition to addressing archival silence(s), some scholars identify black queer legibility as an important theoretical consideration. By black queer legibility, I refer both to the ways in which individuals engaged in same-sex intimacies and gender transgression articulated/understood their identities (based upon race, class, gender, sexuality, region, and space) and how other constituencies perceive those identities. Engaging with Marlon Ross' suggestion of "culturally variant" ways of being, this (il)legibility appears in multiple realms-the archive, popular memory, and even black queer communal politics. Remembering his childhood in Manchester, Georgia, in the 1970s, sociologist Roderick Ferguson (2007, p. 192) argues that black rural "sissies" in his small community "ceased to be peculiar men" to their neighbors during the late 1970s and 1980s, instead becoming "pariahs who had to be identified and excluded." Reverberations of the "civil rights [movement], the Christian Right and modern homosexuality," he asserts, required racial, ideological, and behavioral uniformity that marginalized "black rural sissies" who adopted diverse presentations and articulations of self. In an overlapping time but different place, historian Kwame Holmes argues that the material conditions for identity-based political visibility (including access to public and private space to preserve organizational material) were not as readily available for black queer residents of post-World War II Washington D.C., shaping the development of black gay politics/memory in that city. He calls on scholars to consider the role of "gossip" and "rumor" as critical forms of contemporary political community and a potential historical archive (Holmes, 2015). Performance studies scholar Jeffrey McCune (2014, p. 8) theorizes that a practice of "sexual discretion" which allows some black folk to "negotiate between the acceptable and unacceptable, the respectable and 
disrespectable," to exert "agency under the constraints of surveillance" should shape how we understand varied articulations of black sexual subjectivities past and present. Importantly, Kevin Mumford offers a somewhat different understanding of black queer legibility. In Not Straight, Not white: black Gay Men from the March on Washington to the AIDS Crisis, Mumford (2016, p. 6) argues that during the 1970s and 1980s, black gay men increasingly embraced a "politics of recognition" in which they "chose to speak up against injustice and [articulate] why they needed to come out to remake black gay history." The question of black queer legibility-its implications for political organizing, community building, subjectivities, and more-is an important one that future work should continue to interrogate.

\section{3 | ORIGIN STORIES}

"black culture and history," scholar Matt Richardson (2013, p. 6) notes, "are already always imbued with queerness." "Already always" because sexual non-normativity constitutes the construction of blackness as different and deviant. "Already always" because blackness (with its connotation of sexual difference) emerged as a point of reference for discursive and material conceptualizations of homosexuality. As Tinsley's essay suggests, some scholars identify chattel slavery in the United States as an origin point of black queer histories. There are relatively few studies of this type (which document same-sex intimacies/gender transgression or analyze how the "peculiar institution" informed emerging categories of homosexuality). A potential dearth of archival evidence is one challenge to crafting such studies. A desire to undermine stereotypes about black individual and familial pathology is another. The latter, stated most prominently in the 1965 report "The Negro Family: The Case for National Action" by Assistant Secretary of the Department of Labor Daniel Patrick Moynihan, prompted a generation of scholarship devoted to confirming the ubiquity of two-headed male-female households and normative black familial formations. Crucially, historian of slavery Brenda Stevenson (1996) documents a diverse number of familial formations among enslaved and free black Virginia communities in Life in black and white: Family and Community in the Slave South. Three more recent works indicate the promise of interdisciplinary analyses of gender transgression and/or same-sex intimacies during (and after) the era of slavery. In Against the Closet: black Political Longing and the Erotics of Race, Aliyyah Abdul-Rahman (2012, p. 26) considers how African American literary works from slavery to the present feature sexual and gender non-conformity, arguing that such anti-normativity shapes conceptualizations of freedom. In the monograph's first chapter, Rahman argues that the representation "of sexual perversity under conditions of enslavement" crucially informed concepts and consequences associated with sexual difference (including homosexuality) around the turn of the twentieth century.

In The Delectable Negro: Human Consumption and Homoeroticism within U.S. Slave Culture, Vincent Woodard (2014) explores recurring narratives about the digestion and consumption of enslaved black flesh, incorporating an array of archival sources and controversial moments. In doing so, this work interrogates how homoeroticism undergird interracial intimacies under slavery, excavating an archival record of homosex/same-sex desire. Finally, Thomas Foster's (2011) article "The Sexual Abuse of black Men Under Slavery" documents the presence (and prevalence) of interracial, intragender sexual violence alongside other forms of coercive sexual relations under slavery. Forthcoming work on queerness and slavery-as represented by the Queering Slavery Working Group founded by Jessica Marie Johnson and Vanessa Holden-promises to expand and enrich this area of inquiry.

Scholarship analyzing communities and events during the late nineteenth and first half of the twentieth century is more robust. This is due (in part) to the emergence of (a) medical, juridical, and popular understandings of heterosexuality and homosexuality as distinct identities and behaviors and (b) visible queer subcultures and subjectivities. Both developments precipitated contemporary forms of documentation-including but not limited to police records, newspaper reports, novels and poems, blues songs, and photography. This source base provides glimpses of the various ways that sexual and gender transgressors found intimacy and forged community in the streets, public parks, bars, and clubs. Others pursued careers as entertainers, dancers, and drag performers in the city's popular clubs and cabarets, black and tans or speakeasies as well as the privacy of buffet flats and house 
parties. Works that analyze this vibrant world include Eric Garber's (1991) essay "A Spectacle in Color," George Chauncey's (1994) epic Gay New York: Making of the Modern Gay World, and Marlon Ross' (2004) Manning the Race: Reforming black Men in the Jim Crow Era.

An overlapping group of studies interrogate imbrications of blackness and queerness during the late nineteenth and first half of the twentieth century, moving between the social and textual. In the foundational text Interzones: black/white Sex Districts in Chicago and New York in the Early Twentieth Century, Kevin Mumford (1997) argues broadly that interracial sexual intimacies were consequential in the development of American modernity. A crucial subargument of the book reveals the manner in which blackness-as understood discursively and spatially-shaped responses to and developments of queer subcultures. Interracial spaces like speakeasies, city streets, and other public venues were crucial, he argues, to the delineation of homosexual identities. Mumford's (1997) work demonstrates the interconnected nature of black urbanization and LGBT/Queer community development in ways that continue to inspire forthcoming work. Lisa Duggan's Sapphic Slashers: Sex, Violence, and American Modernity shifts the realm of imbricated blackness and queerness to the widely circulating narrative of the lesbian love triangle murder trial (specifically the 1892 trial of Alice Mitchell in Memphis Tennessee) and commonplace lynchings of black men nationwide. Duggan (2000) considers the "shared logics" of both accounts, arguing that "narrative technologies of sex and violence" stigmatized black and queer populations around the turn of the twentieth century.

Jennifer Terry's (1999) An American Obsession: Science, Medicine and Homosexuality in Modern Society and Siobhan Somerville's (2000) Queering the Color Line: Race and the Invention of Homosexuality in American Culture analyze scientific/medical authorities' mobilizations of racial categories to advance theorizations about the origins and articulations of same-sex desire and/or gender non-conformity. Terry analyzes the preoccupation of physicians, scientists, and cultural critics with homosexuality, arguing that such engagements acted as a crucial avenue to set the boundaries of acceptable forms of behavior-with racial science acting as a crucial reference point. Somerville analyzes sexologist literature and popular representations of same-sex intimacies created by whites and blacks, casting both as crucial origin points for an intertwined history of blackness and homosexuality. She argues that black writers and intellectuals "were able to resist, contest, and appropriate these dominant cultural discourses. At the same time, they often re-inscribed them."

Chad Heap's Slumming: Sexual and Racial Encounters in American Nightlife, 1885-1940 and Shane Vogel's The Scene of Harlem Cabaret: Race, Sexuality, Performance analyze the emergence of a racialized sexual binary-in which blackness and queerness were spatially linked and overlapping-within urban social spaces (dancehalls and cabarets for example) and discourses about these particular spaces during the first half of the twentieth century. Heap (2009) argues that the process of slumming-in which white Americans socialized in urban entertainment spaces that traversed ethnic, racial, and class lines-reinforced a black/white binary of American race relations and helped concretize a homosexual/heterosexual binary. Vogel's (2009, p. 3) interdisciplinary study-firmly rooted in literary and performance studies methods-argues that a particular set of Harlem Renaissance writers, artists, and intellectuals mobilized the cabaret space to "critique the racial and sexual normativity of uplift ideology and to imagine alternative narratives of sexual and racial selfhood." Part II of this essay continues to survey black queer historical scholarship, with particular attention to the themes of gender, class, and political life.

\section{ENDNOTES}

${ }^{1}$ Rosenberg (2017, xvii) characterizes Murray as someone who-if born in a later period-might embrace a transgender identity and masculine pronouns. Her biographer, however, uses the various terms Murray employed to describe herself and uses feminine pronouns. Rosenberg writes "to use male pronouns for someone assigned female at birth in a time when that was not culturally possible, or gender-neutral pronouns when, even to this day, no consensus exists on what those pronouns should be, I concluded, would undercut the immensity of the struggle in which Murray was engaged and the significance of her contributions."

${ }^{2}$ Throughout the essay, I deploy various terms to refer to African American individuals and communities who may have engaged in same-sex sex, intimacies, gender non-conformity, and/or identified as lesbian, gay, bisexual, transgender, queer, same-gender loving, or some other category. Most often, I refer to these communities/ persons as "black queer." Other 
terms litter this essay including sexual and/or gender transgressors, sexual and/or gender non-conformity to designate individuals whose private intimacies and/or public presentation (clothing, mannerisms, behavior, etc.) was not perceived to correspond with prevailing societal norms in a given historical moment. I acknowledge that many historical actors may not have used these particular words/terms/concepts to describe themselves.

${ }^{3}$ These behaviors were associated with homosexuality around the turn of the twentieth century.

${ }^{4}$ The importance of history in black gay and lesbian cultural production is an important antecedent for black queer historical scholarship. For a few important analyses about historical memory and black gay/lesbian cultural production, see Richardson (2013). The Queer Limit of black Memory: black Lesbian Literature and Irresolution. Columbus, OH: Ohio State University Press. Eric Darnell Pritchard. (2017). Fashioning Lives: black Queers and the Politics of Literacy. Carbondale, IL: Southern Illinois University Press.

\section{ORCID}

Jennifer Dominique Jones (D) https://orcid.org/0000-0002-2463-0280

\section{REFERENCES}

Bérubé, A. (2001). How gay stays White and what kind of White it stays. In B. B. Rasmussen, E. Klinenberg, I. J. Nexica, \& M. Wray (Eds.), The making and unmaking of whiteness (pp. 234-265). Durham, NC: Duke University Press. https://doi.org/ 10.1215/9780822381044-011

Chauncey, G. (1994). Gay New York gender, urban culture, and the makings of the gay male world, 1890-1940. New York, NY: Basic Books.

Duggan, L. (2000). Sapphic slashers: Sex, violence, and American modernity. Durham, NC: Duke University Press. https://doi. org/10.1215/9780822381013

Dunye, C. (1996). The watermelon woman. United States of America: First run features.

Ferguson, R. A. (2007). Sissies at the picnic: The subjugated knowledges of a black Rural Queer. In K. E. E, H. K. Aikau, \& J. Pierce (Eds.), Feminist waves, feminist generations: Life stories from the academy (pp. 188-196). Minneapolis, MN: Univerity of Minnesota Press.

Foster, T. (2011). The sexual abuse of Black men under slavery. Journal of the History of Sexuality, 20, 445-464. https://doi.org/ 10.1353/sex.2011.0059

Garber, E. (1991). A spectacle in color: The lesbian and gay subculture of Jazz Age Harlem. In M. Vicinus, G. Chauncey, \& M. B. Duberman (Eds.), Hidden from history: Reclaiming the gay and lesbian past. New York: Penguin Books.

Gomez, J. A. Cultural legacy denied and discovered: Black Lesbians in fiction by women. In B. Smith (Ed.), Home girls: A Black feminist anthology (pp. 110-123). New Brunswick, NJ: Rutgers University Press.

Heap, C. C. (2009). Slumming: Sexual and racial encounters in American nightlife, 1885-1940. Chicago: University of Chicago Press.

Higginbotham, E. B. (1993). Righteous discontent: The women's movement in the black Baptist Church, 1880-1920. Cambridge, Mass: Harvard University Press.

Hine, D. C. (1989). Rape and the inner lives of black women in the Middle West. Signs, 14(4), 912-920. https://doi.org/ $10.1086 / 494552$

Holmes, K. (2015). Wha't the tea: Gossip and the production of black gay social history. Radical History Review, 2015(122), 55-69. https://doi.org/10.1215/01636545-2849531

Hull, A. GloriaUnder the days: The buried life and poetry of Angelina Weld Grimké. In B. Smith (Ed.), Home girls: A black feminist anthology (pp. 73-82). New Brunswick, NJ: Rutgers University Press.

Lorde, A. (1982). Zami: A new spelling of my name. Berkeley, CA: Crossing Press.

Marsh-Edwards, N., \& Julien, I. (1989). Looking for Langston. United Kingdom: British Film Institute.

McCune, J. Q. (2014). Sexual discretion: black masculinity and the politics of passing. Chicago, IL: The University of Chicago Press.

Mitchell, M. (1999). Silences broken silences kept: Gender and sexuality in African-American history. Gender \& History, 11 , 433-444. https://doi.org/10.1111/1468-0424.00154

Mumford, K. J. (1997). Interzones: black/White sex districts in Chicago and New York in the early twentieth century. New York, NY: Columbia University Press.

Mumford, K. J. (2016). Not straight, not White: black gay men from the March on Washington to the AIDS crisis. Chapel Hill: The University of North Carolina Press.

Rahman, A. A. (2012). Against the closet identity, political longing, and black figuration. Durham, NC: Duke University Press. 
Reid-Pharr, R. (2006). black Sexuality Studies. Retrieved March 1, 2017 http://bsc.chadwyck.com.proxy.lib.umich.edu/ search/displayEssayltemByld.do?ItemID=13PHAR\&ItemNumber=3\&QueryName=essay\&fromPage=essayList

Richardson, M. (2013). The queer limit of Black memory: Black lesbian literature and irresolution. Columbus, OH: Ohio state University Press.

Rosenberg, R. (2017). Jane crow: The life of Pauli Murray. New York, NY: Oxford University Press.

Ross, M. B. (2004). Manning the race: Reforming black men in the Jim Crow Era. New York, NY: New York University.

Ross, M. B. (2005). Beyond the closet as a racelss paradigm. In E. P. Johnson, \& M. G. Henderson (Eds.), black queer studies: An anthology (pp. 161-189). Durham, NC: Duke University Press.

Somerville, S. (2000). Queering the color line: Race and the invention of homosexuality in American culture. Durham, NC: Duke University Press.

Stevenson, B. (1996). Life in black and White: Family and community in the Slave South. Oxford, UK: Oxford University Press.

Terry, J. (1999). An American obsession: Science, medicine, and homosexuality in modern society. Chicago, IL: University of Chicago Press. https://doi.org/10.7208/chicago/9780226793689.001.0001

Tinsley, O. (2008). black Atlantic, queer Atlantic: Queer imaginings of the middle passage. GLQ, 14, 191-215. https://doi.org/ 10.1215/10642684-2007-030

Vogel, S. (2009). The scene of Harlem Cabaret: Race, sexuality, performance. Chicago, IL: University of Chicago Press.

Woodard, V. (2014). The delectable negro: Human consumption and homoeroticism within US slave culture. New York, NY: New York University Press.

\section{AUTHOR BIOGRAPHY}

Jennifer D. Jones is an LSA Collegiate Fellow in the Department of History at the University of Michigan. Jones received her doctoral degree in American History from Princeton University in 2014 and a Bachelor of Arts Degree with Distinction from the University of Michigan in 2007. She is currently working on a book monograph titled "Queering An American Dilemma: Sexuality, Gender, and Race Relations in the United States, 1945-1988." In this project, Jones analyzes how the increasing visibility and political organizing of gay and lesbian communities reverberated into 20th century campaigns for and contests over racial equality.

How to cite this article: Jones JD. Finding home: Black queer historical scholarship in the United States Part I. History Compass. 2019;17:e12532. https://doi.org/10.1111/hic3.12532 